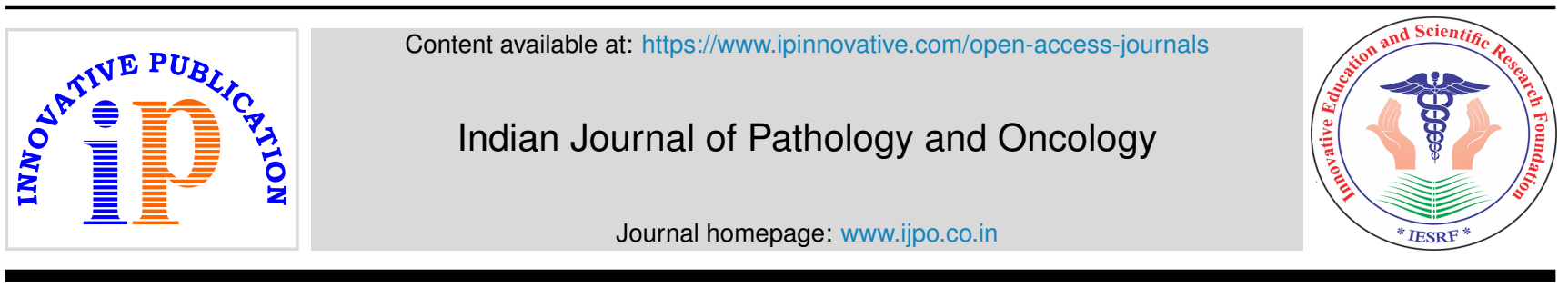

\title{
Editor Desk
}

\section{From Editor's Desk}

\author{
Ranjan Agrawal ${ }^{1, *}$ \\ ${ }^{1}$ Dept. of Pathology, Rohilkhand Medical College \& Hospital, Bareilly, Uttar Pradesh, India
}

\section{A R T I C L E I N F O}

Article history:

Received 13-05-2021

Accepted 12-05-2021

Available online 19-05-2021
(C) This is an open access article distributed under the terms of the Creative Commons Attribution License (https://creativecommons.org/licenses/by/4.0/) which permits unrestricted use, distribution, and reproduction in any medium, provided the original author and source are credited.
Dear Readers,

IJPO has progressed with every issue it is coming out with. Authors and reviewers both have to be complimented for their efforts. Every issue is blended with a mixture of articles on different topics that cover the vast spectrum of pathological entities.

Renal cell carcinoma accounts for the majority of malignancies of kidney and is more common in the West. Study by Ramchandra et al. tabulated their data of 60 cases. Categorisation of the tumour was done as per the latest guidelines. ${ }^{1}$

Breast carcinomas are on the rise even in developing countries probably due to early and timely diagnosis. Prabhu et al. in their study have meticulously taken into consideration various parameters that carry an impact on the prognosis of breast carcinoma. ${ }^{2}$ Bhuvneshwari et al. in their study highlighted the role of Vimentin, a mesenchymal immunohistochemical marker. They reported that vimentin is expressed in high grade breast carcinomas but at the same time their expression did not correlate with either the tumour size or metastases into the lymph nodes. The authors further concluded that use of Vimentin could be of help in cases of breast carcinoma that were independent of other prognostic parameters. ${ }^{3}$

\footnotetext{
* Corresponding author.

E-mail address: drranjan68@gmail.com (R. Agrawal).
}

Astrocytomas constitute an important group of brain tumours that are fatal and may often be misdiagnosed or missed on routine biopsy. Bisht et al. in their study using four markers of proliferative index concluded that PHH3 and Mitosin are especially important markers that may help in the histopathological diagnosis and grading of Astrocytomas. ${ }^{4}$

Liver diseases comprise an important category of childhood diseases. Many of the cases due to other overlapping clinical presentations remain undiagnosed for long. Although many patients do not require biopsy for diagnosis, chronic and long- standing cases or those that do not respond to treatment require histopathological comfirmation. Article by Amin et al. has categorized histopathological findings in childhood liver diseases emphasing the role of biopsy in the confirmation of diagnosis. 5

I am sure that the readers would appreciate and love reading the articles published in this issue.

Happy reading

Jai Hind!

\section{References}

1. Ramchandra S, Amoncar S, Raiturkar SP, Prabhudesai M, Pinto RGW. A histopathological study of renal cell carcinoma at a tertiary care hospital. Indian J Pathol Oncol. 2021;8(2):193-7. 
2. Prabhu SC, Umashankar T. A study on Nottingham prognostic index and its correlation with ER, PR, Her-2 Neu and Ki-67 in breast carcinomas. Indian J Pathol Oncol. 2021;8(2):188-92.

3. Bhuvaneshwari K, Vani D. Expression of vimentin in breast carcinoma and its correlation with histopathological parameters. Indian J Pathol Oncol. 2021;8(2):207-12.

4. Bisht DS, Deb P, Sharda H, Bisht S. Comparison of mitosin and PHH3 indices with mitotic index and Ki-67 labelling index in diffusely infiltrating gliomas. Indian J Pathol Oncol. 2021;8(2):175-82.

5. Amin Y, Jagadale K, Nimbargi RC. Clinicopathological study of liver diseases in paediatric age group. Indian J Pathol Oncol. 2021;8(2):23240 .

\section{Author biography}

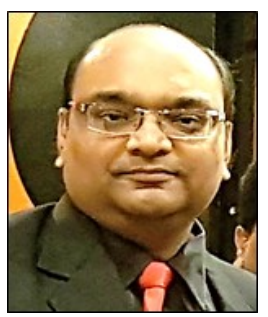

Ranjan Agrawal, Professor (MD; FIC Path;

MIAC, DHA) Editor-in-Chief, IJPO

Cite this article: Agrawal R. From Editor's Desk. Indian J Pathol Oncol 2021;8(2):173-174. 